\title{
The Snake and Zig-Zag Motifs in Finnish Rock Paintings and Saami Drums
}

\author{
By Eero Autio
}

In articles about Finnish rock paintıngs particular attention has been paid to the significance of shamanısm (e g Siikala 1980; Miettinen 1982) The emphasis on shamanism leads in practice to the conclusion that a composition in which there is a man and a snake, or a snake like zig-zag figure, depicts a shaman and his helping animal

The explanation follows the traditional concept of arctic shamanism and gains support from Skanke-Jessen's statement about this motif on Saamı drums In many cases I have found, however, that the use of shamanism as the most significant basis for interpretation does not lead to plausible results in the study of pictographs (rock paintings) and petroglyphs (rock carvings) The location of the figures of a snake or zig-zag on the surfaces of the Asele-type drums is also puzzling I am not convinced that this can be co-ordinated with the Scandinavian Nidhöggr as Bo Sommarström (Sommarström 1987, 223) has suggested

In the Finnish pictographs the figures of a snake or zig-zag can only be found in the rock paintings of Sarakallio in Laukaa (in Central Finland), Juusjärvı in Kirkkonummı (near Helsinki), Kolmiköytınen in Ruokolahtı (on the eastern shore of lake Sarmaa), Mertakallio in Iitti (in Southern Finland) and Haukkavuorı (in eastern Finland)

One of the snake figures on the rock at Sarakallio is situated very near another figure which has been supposed to represent some kind of lizard, (Fig 1a) An almost similar drawing can be traced in the Karelian petroglyphs (Fig 1b) Both figures seem to belong to the cult of the phallus, which was popular, especially in the bronze age If the snake and the phallistic painting at Sarakallio can be linked together, then the composition has a counterpart in the old Celtic world (Fig 1c) The man in the picture has been thought to represent some god, most likely Cernunnos, because that god was depicted with a snake in the petroglyphs of Val Camonica (MacCana 1983, 39, 42)

Another zig zag motif from Sarakallio can be seen in fig 1d Below the zig zag there are two boats and on the right human figures standing 


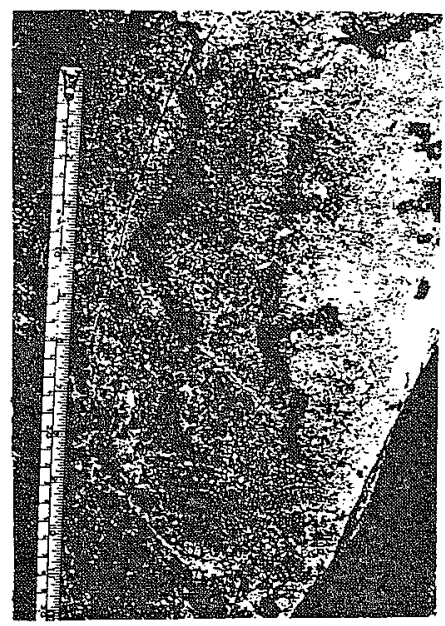

Fig 1 a Rock paintings at Sarakallio (MV Miettinen \& Miettinen 1978)

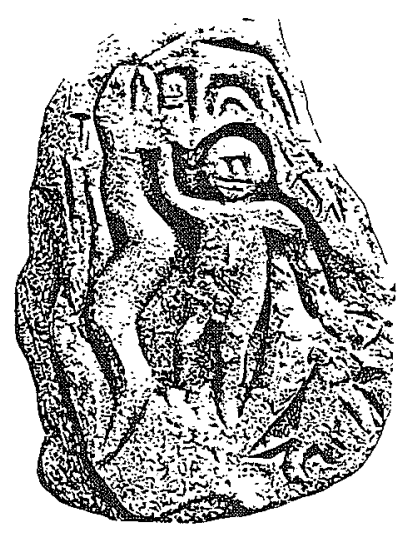

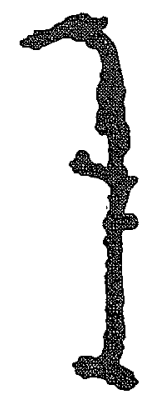

Fig $1 b$ A rock carving on Lake Äännen (Raudonikas 1936-38 1, tab 4)

Fig 1c A god with a snake (Schlette 1976, 125)
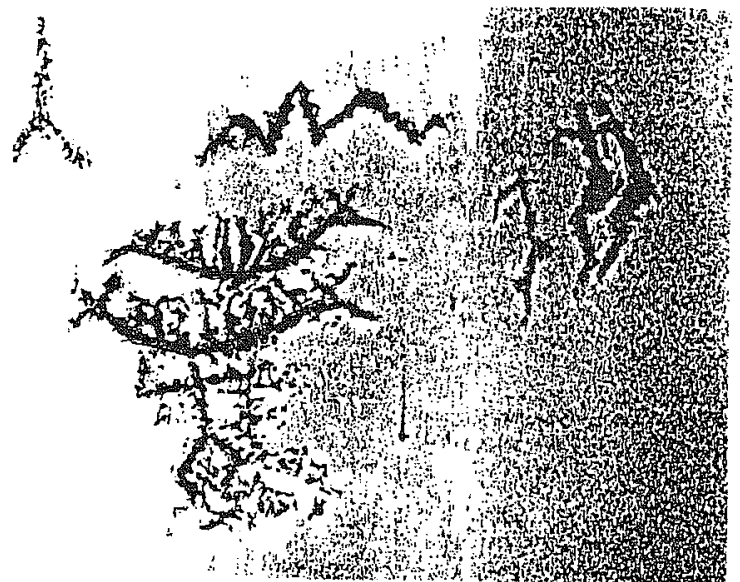

Fig 1d Rock paintings at Sarakallio (MV Miettinen \& Miettinen 1978) 
one behind the other My initial idea, on examining the human figures from Sarakallio, was that almost the same kind of "acting" can be found in the Karelian rock carvings, especially at the mouth of the nver Uikujokı (Vyg) (Fig 1e) The Karelian "scene" is so vivid that anyone can see what is taking place in the picture

The function of the kind of copulation performed by the human beings is magical and it belonged to the cult of fertility (Autio 1981, 89) The animal masks of the human beings also indicate this The statement fits well with the observation that the quantity of elk bones at the sites of the comb-ceramic culture is smaller than in the earlier phase or so called Suomusjärvi culture The explanation for this is that the elk was becoming rare (Salo 1984, 72)

Just under the boats there are two human figures, as if they are holding up the boats Almost similar compositions can be seen in the Scandinavian petroglyphs (Fig 1f) The archaeologist Göran Burenhult has proved by reference to the Egyptian votive boats to the dead and above all by Danish prehistoric finds (Fig 1g), that the motif of the so-called "boat-carrier" represents a votive offering to the fertility-goddess (Burenhult 1979, 17 ff) It seems to me that the composition of the Laukaa picture also depicts a votive-offering The suggestion would obtain support from the information provided by Rheen According to this, the Saamis used to make a boat of birch bark, pour some fat into it and hang the "the boat-offering" on a tree for the spirits hovernng at Christmas (Manker 1950, 57)

Probably "the hovering spirits" were the ghosts of the dead, which were believed to enter the world of the linng between the old and the new year The belief was common in Europe before the Christian farth (James 1959, $140 \mathrm{f}, 316 \mathrm{ff}$ ) and the kindred peoples of the Finns in Eastern Europe also knew 1 t and entertaned their ancestors and dead relations according to this custom (Waronen 1895, $110 \mathrm{f}$., 115, $118 \mathrm{ff}$, Holmberg 1914, $41 \mathrm{ff}, 51$ )

In the composition of Sarakallio there are two human beings, while in the Swedish parallel there is only one I assume that the figures of Sarakallio depict a man and a woman If this is so, then the man and his wife in the painting are serving together The explanation would agree with the information I obtained from Oula Näkkäläjärv1 and Iisko Sara in Turku (20 8 1988) that the father's and mother's family and their ancestors are of equal importance to the Saami people This information also explains the meaning of the two boats in the composition: one is for the man's ancestors and the other for the woman's As far as the equality of men and women is concerned, the 

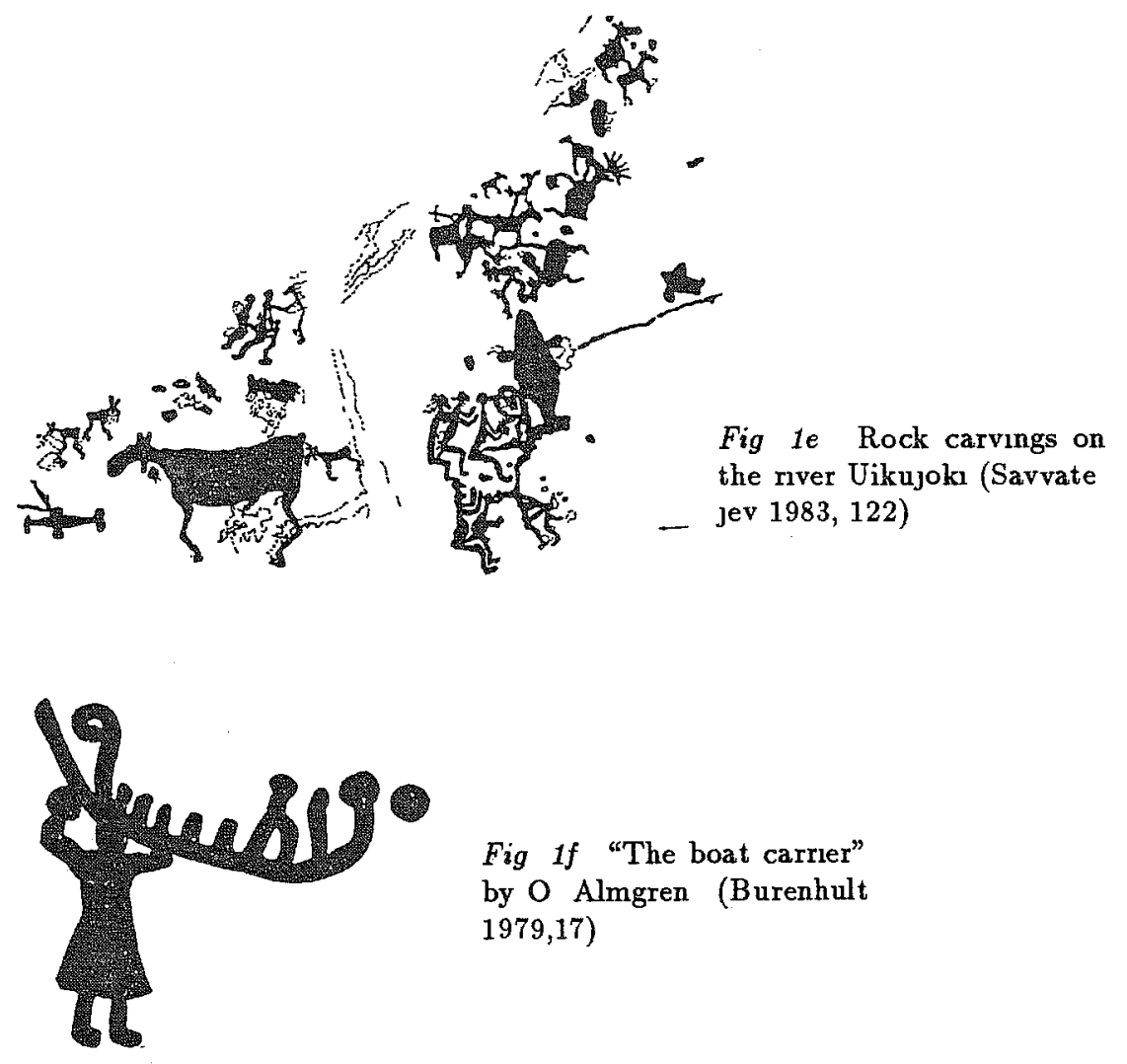

Fig if "The boat carrier" by $O$ Almgren (Burenhult 1979,17)

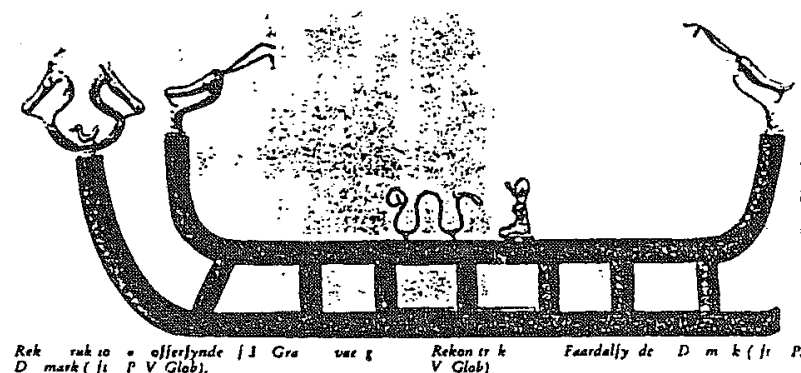

Fig $1 g$ A reconstruction of a Danush votive offering boat (Burenhult 1979, 18)

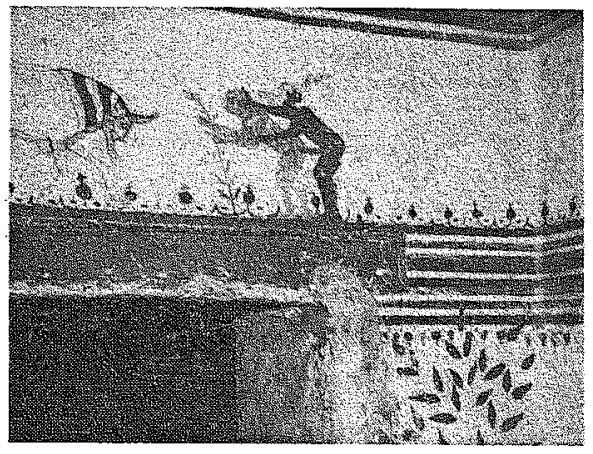

Fig 1h An Etruscian tombpamting Photo: $S$ Autio, 1982 

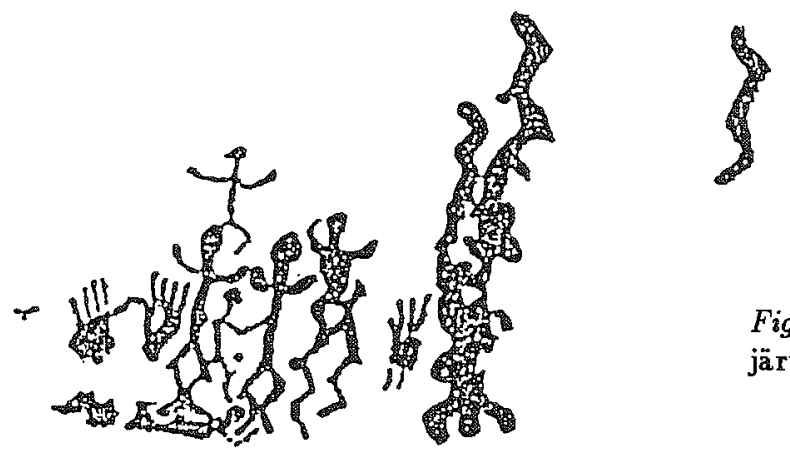

Fig 2 Rock paintings of Juus järvı (Luho 1964, fig 6)

explanation gains support from the use of the 3rd person pronoun in all the Fenno Ugrian languages: there is only one word for man and woman instead of two (he and she) We do not place men and women into separate categories as in the Indo European languages

The zig-zag motif of Sarakallio can be simultaneously associated with the cults of ancestors and fertility In the past these two spheres have not been separate, as may be seen from Etruscan tomb-painting (Fig 1h) The fertility and ancestor cults were carried on side by side in the old calendar festivals like "kekri" in eastern Finland Behınd the traditions there seems to have been a belief, held for example by the Votyaks, according to which ancestors, as well as the gods, were able to help their descendants (Holmberg 1914, $51 \mathrm{f}$ ) This matches well with further informatıon obtained from Oula Näkkäläjärvı and Iisko Sara regarding the terms for ancestors in lineal descent The words in use for the 3rd and older generations are "māttar áhkku" on the mother's side and "māttar áddja" on the father's Both of these words may be associated with the gods, according to Näkkäläjärvı and Sara This was so in every Saamı dialect (Ränk 1949, 189)

As the zig zag in the composition is not vertical but horizontal, this may also have some meaning Perhaps it is worth noticing that there are seven bends in the figure This number also occurs in the Uralian counterparts

In the rock paintings of Juusjärvı, fig 2, the snake like figures are on the right No doubt they have some meaningful connection to the other figures The interpretation based on shamanism seems to be possible, especially as one of the human figures in the picture seems to resemble a hybrid of snake and man The figures of two palms on the left, if they symbolize "the spirit of hands or the place", as Anna Leena Siikala believes (Siikala 1980, 186), would support the explanation based or. shamanism 


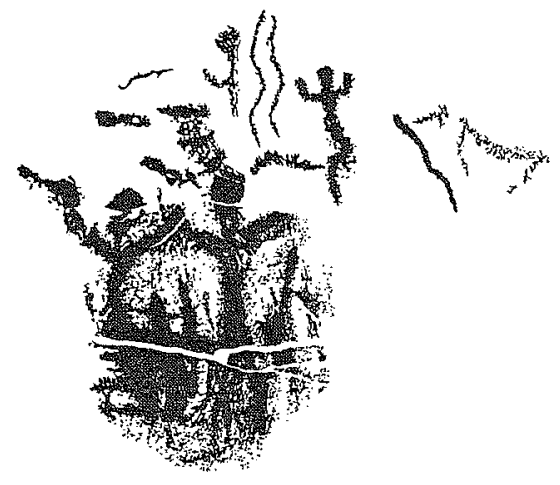

Fig 3a. Rock paintings at Kolmiköyti nen (TY Miettinen 1987)

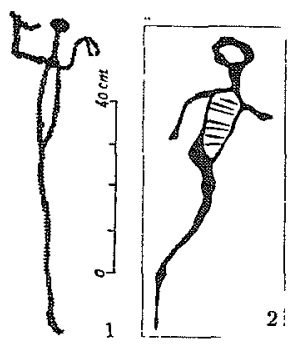

$F i g ~ s b$ Long-legged human being in the petroglyphs of

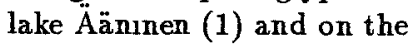
river Tom (2) (Raudonikas 1936-38, 1, tab 28; Okladnikov \& Martynov 1972, 210)

But two palms with the thumbs touching each other may mean quite different things: it may be possible that an ancient panter wanted to indicate the number 'ten' This number had a very great significance in the past A Soviet scholar, B A Frolov, has studied the frequencies of numbers in palaeolithic art and why certain numbers have been used more frequently than others His conclusion is that the number 'ten' was often used, because it was the number of the fingers and showed the length of pregnancy, which lasted ten Lunar months (Frolov 1974, $131 \mathrm{f}$ )

The number ten can be identified in the ornaments of Finnish combceramic pottery Although the few reconstructions are not sufficient evidence, they invite us to consider other possibilities than those based on shamanism For this reason, I agree with the archaeologist Ville Luho, according to whom the Juusjärvi palntings may in some way be associated with the magic of fertility (Luho 1962, 71)

In the paintıngs at Kolmiköytınen in Ruokolahtı there are figures of a snake and an almost sımilar hybrid to that in Juusjärvı (Fig 3a) Timo Miettinen (TY Miettınen 1987) has suggested that the Kolmiköytınen hybrid depicts a shaman on the way to the other world The figure with a long-looking leg also occurs in the petroglyphs of Nämforsen (Hallström 1960, 349), in Karelia, and on the River Tom in Western Siberia (Fig 3b) According to A P Okladnikov, who is a well-known expert on rock art, these kinds of figures may represent some spiritual being (Okladnikov \& Martynov 1972, 210) Since the large-sized human figures at Kolmiköytınen, as if they were dancıng, emphazise 
the ritualistic nature of the paintings, shamanism might be a possible explanation The snake close by the figure of an elk has a counterpart in Siberian petroglyphs According to Okladnikov the combination belongs to the cult of fertility (Okladnikov 1966, 118)

In the pantings at Mertakallio in Iitti (Fig 4a) the figures of a zig zag and a human being may be seen Below these there is another human being although very unclear About $15 \mathrm{~m}$ above the drawings in the picture there is the figure of an elk The combination of a human being and a snake may also be seen in the rock paintings of Haukkavuorı in Enonkoskı (Fig 4b) if we agree with Timo Miettinen, who considers that these may possibly be explaned by shamanism Although Miettinen emphazises the significance of shamanism, he also considers hunting magic and the cult of fertility In his own words the latter was " deeply understood, behind everythıng" (Miettinen 1982, 11)

In order to create a broader perspective for the subject, we must consider at least the Scandinavian, Karelian and Uralian rock pictures In Scandinavia the motif was common, especially in the bronze age, and has a clear connection with the cult of fertility (Figs 5a, 5b; see also fig 1g) The most interesting but "hardest to interpret", as Hallström (Hallström 1960, 17) puts it, is the group of paintıngs from Hästskotsjärn (Fig 5c) At first glance, the combination of figures is very shamanistic: one of the snakes has even been placed on the headdress of the man But the man seems to me to be happy or cheerful rather than frightened The hips, the ray-like lines coming from them and a carving in Alta fjord, the "Kvinne som sitter pa et reinsdyr" (Fig 5d) incline me to believe that the composition of Hästskotsjärn has a mythical background and a connection with the cult of fertility

The snake motif also appears in Alta $^{1}$ (Fig 5e) According to Dr Knut Helskog, the figure of the human being may depict a mythical being or a shaman in a trance (Helskog 1988, 110) The latter interpretation would be supported by some Siberian petroglyphs, e $g$ fig $5 f$, which has been interpreted as a shaman (Okladnikov 1966, 137) But in Alta, even on the same rock, there are figures of human beings inside which there has been placed another human being or a reindeer or something else (Helskog 1988, $66 \mathrm{f}$ ) For this reason, and because of two reindeer which seem to belong to the composition, I think that the explanation of "mythical being" is more plausible than

1 Knut Helskog (Helskog 1985) in his article on rock carvings and Saamı drums does not treat the snake motif separately 


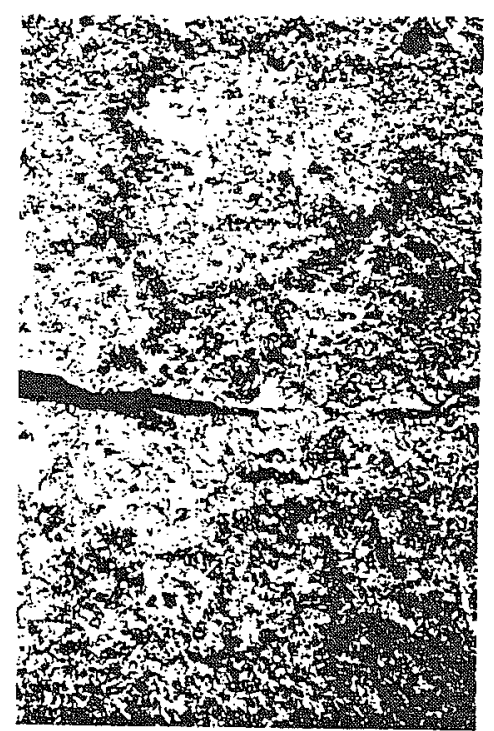

Fig 4a Rock paintings at Mertakallio in Iitti (OJonen 1973, 39)

Fig $4 b$ Rock paintings at Haukkavuon 1n Enonkoska (Sarvas \& Taavitsainen 1975, 135)

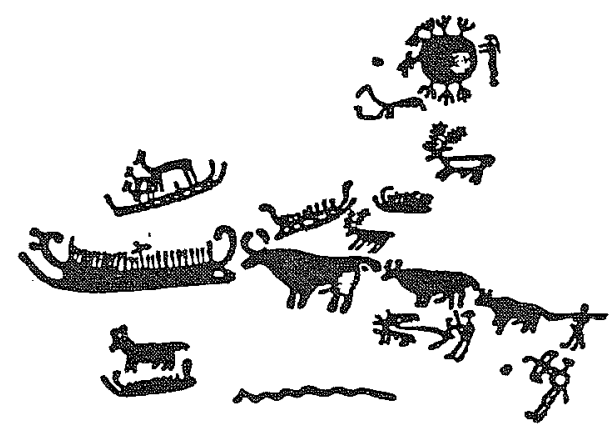

Fig 5a A snake motif in Tannum (Hagen 1976,80 )

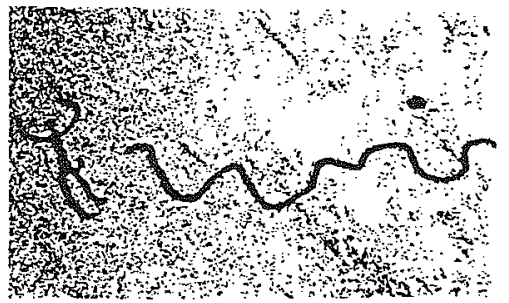

Fig $5 b$ A snake and a man in Tannum (Burenhult 1979, 32) 
60 Eero Autio
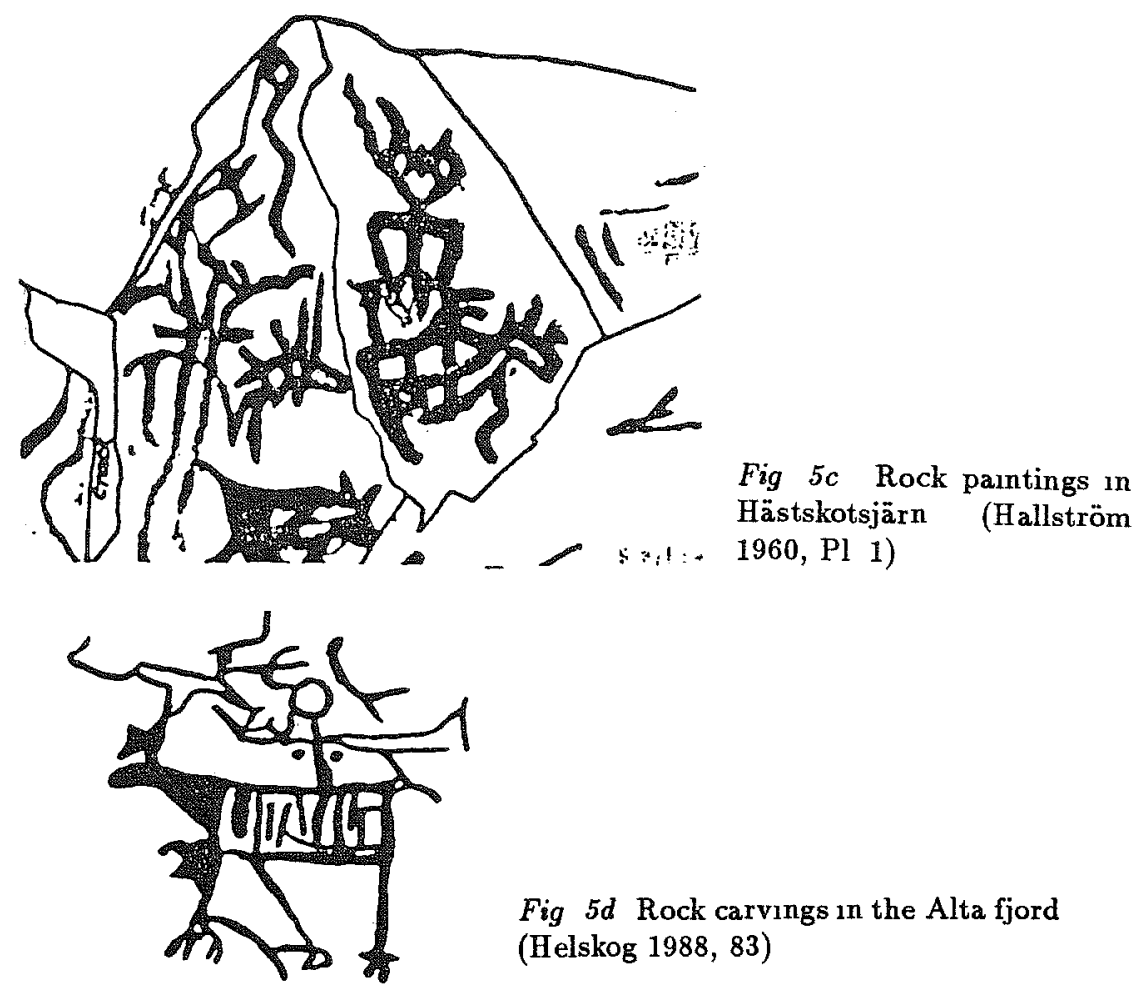

Fig $5 d$ Rock carvings in the Alta fjord (Helskog 1988, 83)

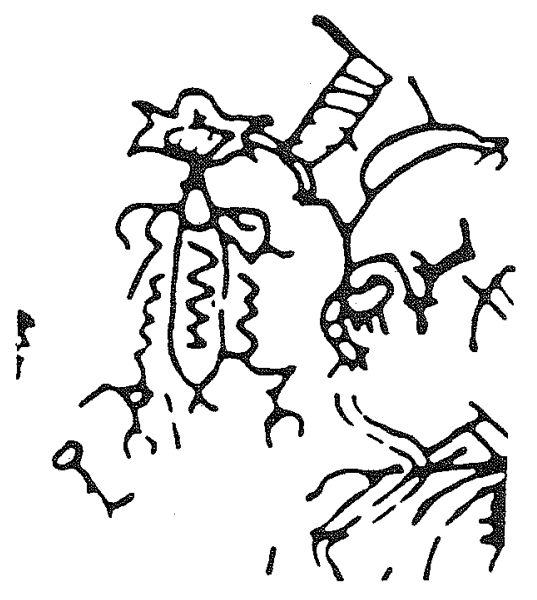

Fig $5 e$ Rock carvings in the Alta fjord (Helskog 1988, 67)

Fig 5f "A shaman" in the Siberian petroglyphs (Okladnikov 1966 137)

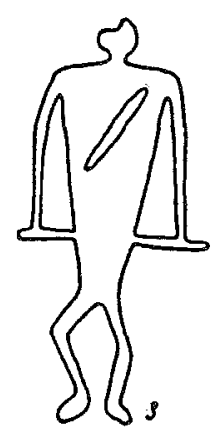


that of "shaman"

In the Karelian petroglyphs the snake may be seen extremely clearly both at the river Uikujoks and on the eastern coast of Lake Äänınen (Onega) In the main group of carvings at Old Zalavruga (Fig 6a) one snake is on the left of the athletic man standing in the middle It has been supposed that the man may represent a great shaman or some deity favourable to hunters (Linevskı 1939, 179; Raudonikas 1936-38, 2,48 )

At the bottom of the picture there is another snake It is situated by the hind leg of the sixth reindeer from the nght This unusual combination has given me reason to compare it with the Ingrian rune of "Elk and snake" (Autio 1984) The motif was popular in the Middle Ages in Europe but goes back to antıquity According to this motıf, the elk kills the snake; according to the Ingrian verses, the elk only kucks the snake in the ribs Whilst the snake is moaning on its side, Margaret's mother comes and milks it and the milk falls onto the ground, at which trees and nature begin to prosper I assume that the snake in the rock carvings had some kind of positive meaning for those who made the pictures at Zalavruga The same may be the case with the snake figures in the southern group at Zalavruga (Fig 6b), although the man in the composition seems to be warding off the snakes

The third example of the Karelian rock carvings is from Lake Äänınen (Fig 6c) I have chosen this because of the short lines or "appendages", found in the bends of the snake These feature can also be seen in the snake of Juusjärvı (Fig 2) and in the Urals (Figs $7 \mathrm{a}, 7 \mathrm{~b}$ )

The zig zag motifs, like those in the pictures just mentioned, are characteristic of the Urals V N Chernetsov, the archaeologist and lingurst, found counterparts to these kinds of motifs in the ornaments of the Ob Ugrians, in the decorations of bronze age ceramics and on a neolithic spear head found in Shigirskı (Chernetsov 1971, 37, 107 f.) He usually interprets zig-zag motifs such as those in figs $7 \mathrm{~b}$ and $7 \mathrm{c}$ as depicting catching fences (Chernetsov 1964, 24; Chernetsov 1971, $64 \mathrm{ff})$ Although I question the interpretation, at least in these cases, I am not able to say whether the motif has any connection with the snake either

A plain snake, as in fig $7 \mathrm{~d}$, is rare in the Urals According to Chernetsov, the whole group depicts the hunting of water birds (Chernetsov 1964, $39 \mathrm{f}$ ) The position of the snake makes me doubt this interpretation The snake motif appears in the Urals as early as the palaeolithic wall painting in the cave of Jamazy Tash (Fig 7e) 


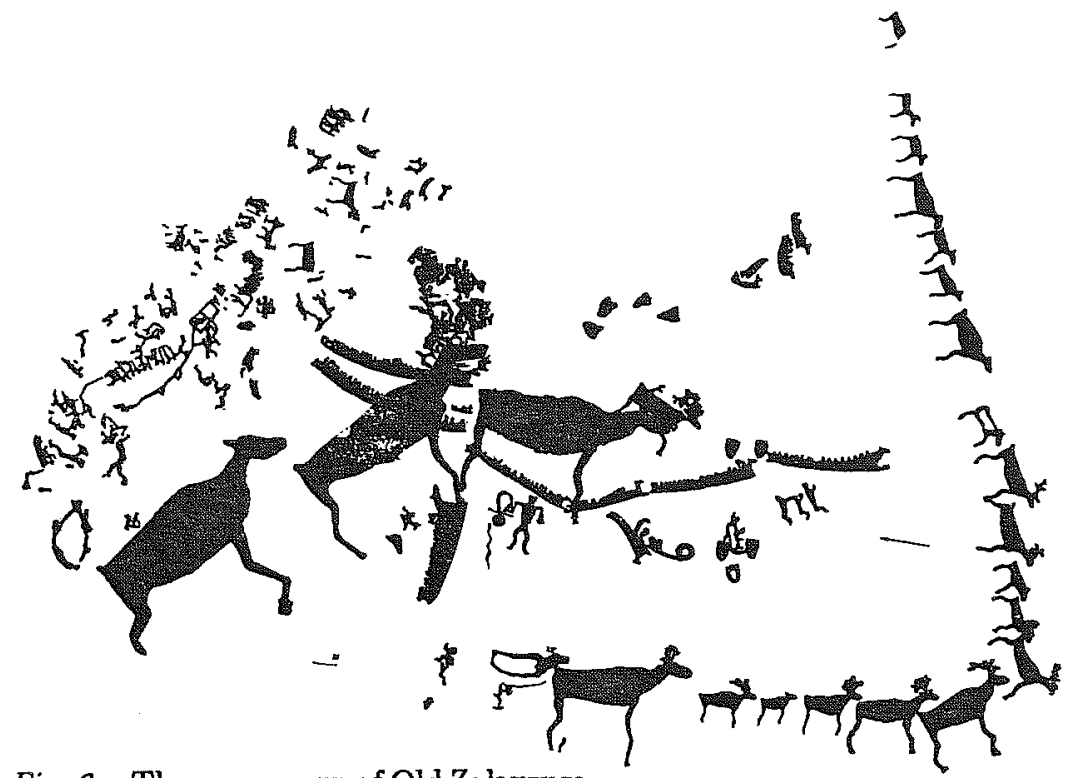

Fig $6 a$ The main group of Old Zalavruga (Raudonikas 1936-38, 2, tab 2)

Fig 6c The snake in the petroglyphs of Lake Äänınen (Estonian copies in the Kare lian Rock Art Exhibition in Kotka 1986 Photo: E Au tio)

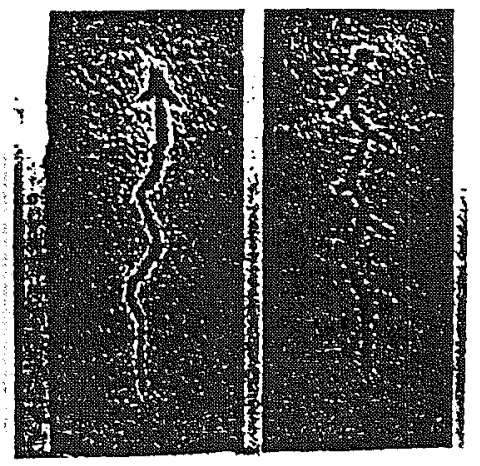

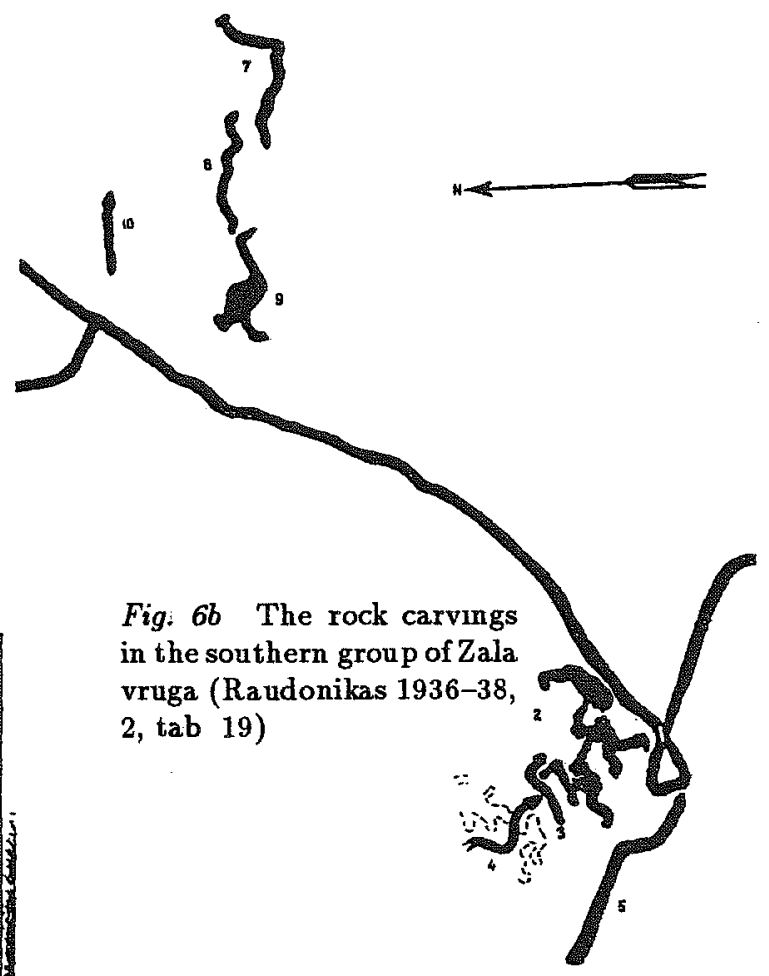




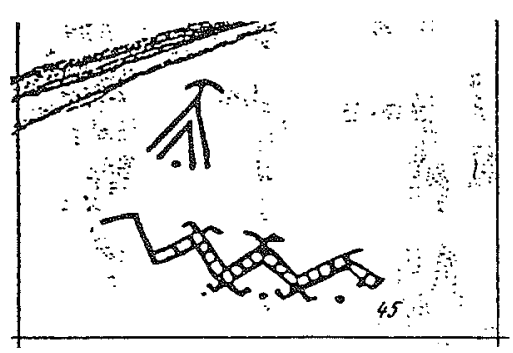

Fig $7 a$ A zig zag motif in the Urals (Chernetsov 1971, tab 14)

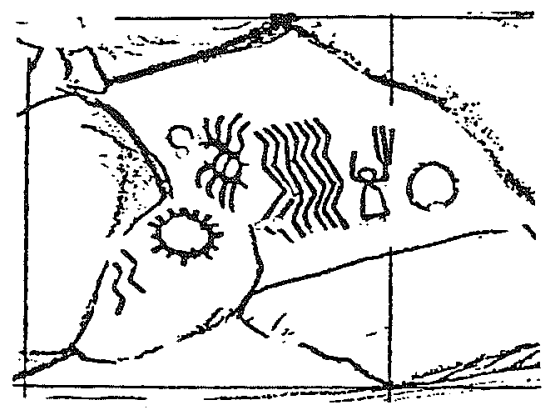

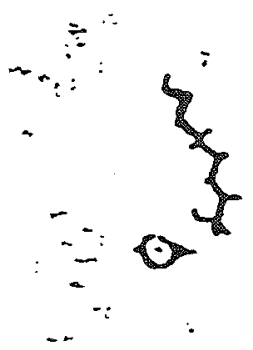

Fig $7 b$ A zig zag motif in the Urals (Chernetsov 1964, tab 26)

Fig $7 c$ Rock paintings in the Urals (Chernetsov 1964, tab 23)
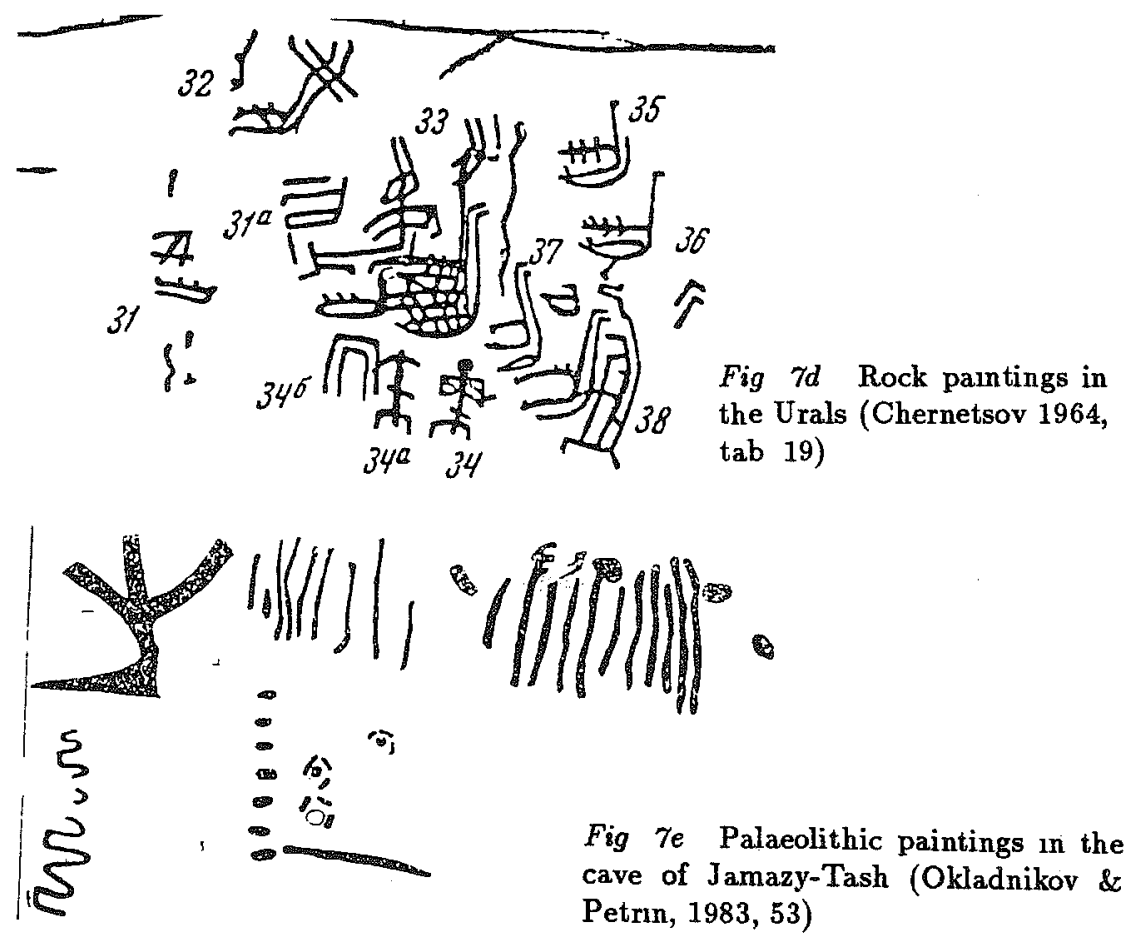
Okladnikov and V T Petrin, who have examined the paintıngs in the cave, have noticed that "the magical number seven" can also be seen on the bends of the snake (Okladnikov \& Petrin 1983, 54) It is worth mentioning that the same number occurs very often in the later paintings of the Urals and also in our figs $7 \mathrm{a}$ and $7 \mathrm{c}$

I have extended my survey to the Urals and even farther, because "it is to the east we must look for the hunters' and fishermen's cultures" (Gjessing 1978, 21, Aspelin 1877) On the basis of the evidence, Chernetsov has pointed out that the Uralian rock paintings were made by the ancestors of the Voguls The ancient comb ceramic culture in its different variants stretched from Western Siberia to Northern Scandinavia, and the commercial links of the time are not without significance: evidence of this is a spoon made of Siberian pine discov ered in Laukaa

The Ural world supposedly has a great importance for Saamı drums, too The similarities in the languages of the Saami and the $\mathrm{Ob}$ Ugrians, the matriarchal features of their deities, and other similarities in their religions, observed by Gustaf Ränk and many others, support this conclusion And it is not mere chance that solar symbolism plays a central part both in the Saamı drums and in Uralian (also Siberian) rock art The Ob Ugrian model of the three worlds, the underworld, this world and the upper world, is a detail, which can also be identified on the Saami drums

The Saami drums can be divided into those in which the symbol of Päivö, the sun, with its reins (labikies), is situated in the middle of the drum heads, and those whose illustrated surfaces are separated into two or more sections The first mentioned, or so called $\AA$ sele type, is considered to be of an older style than the others It is therefore more suitable from the point of view of rock pictures and deserves our chief attention The pictures and statements concerning the drums are from Ernst Manker's Die Lappische Zaubertrommel I-II, unless otherwise stated (Manker 1938; Manker 1950)

The snake or zig zag motif occurs in 30 Asele drums and is situated on the left of the symbol of Päivö (Tab 1A) There are only two exceptions In drum 36 (the undefined zig zag) it is on the right, up by the figures of Radien attje, the highest god, and a tree supposed to be the symbol of growth The other one is drum $32 \mathrm{in}$ which the 


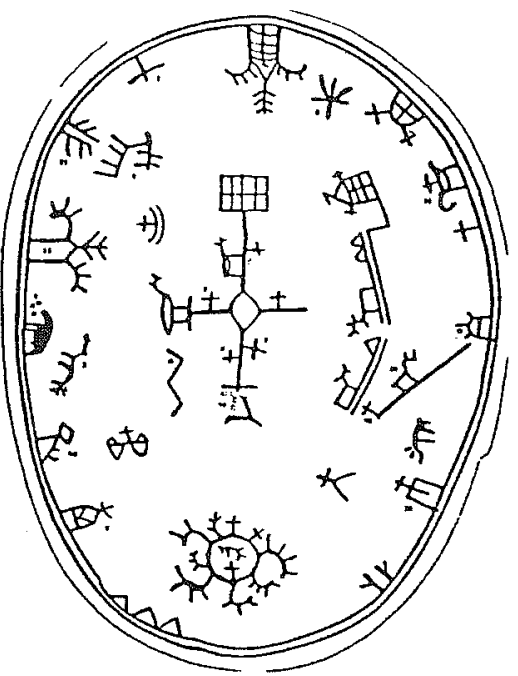

Fig 8a. Drum number 35 (Manker 1950).

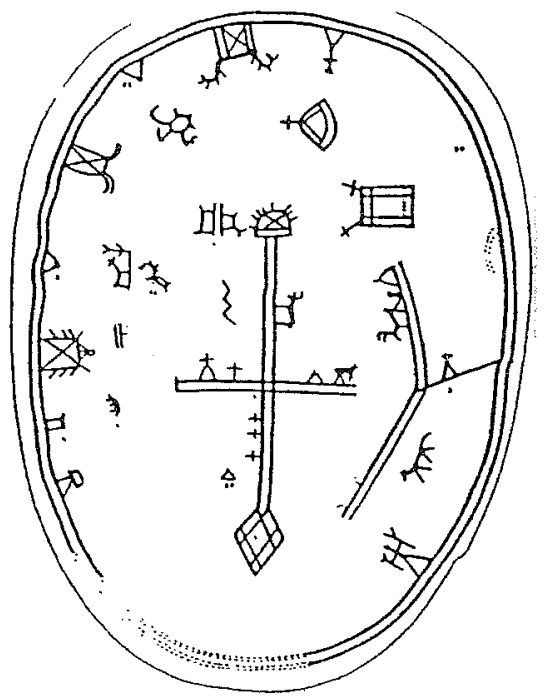

Fig $8 b$ Drum number 2 (Manker 1950)

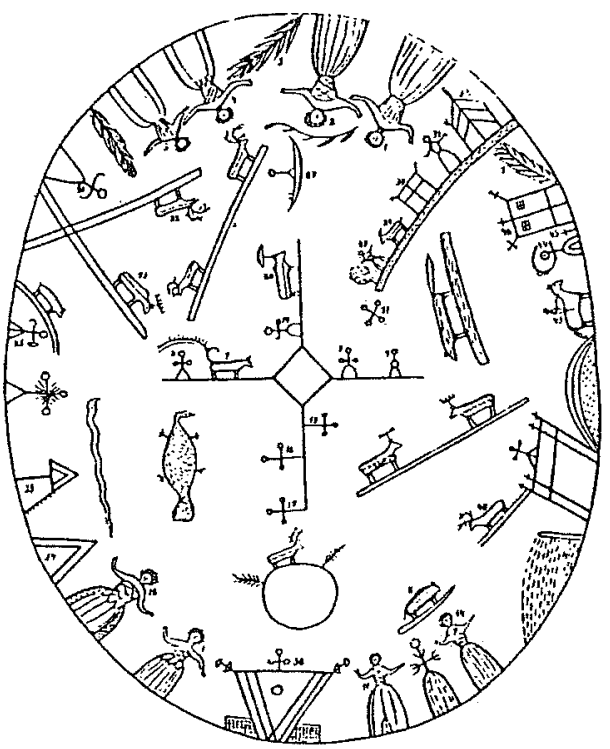

Fig $8 c$ Frees' drum 2 (Manker 1950, fig 79)

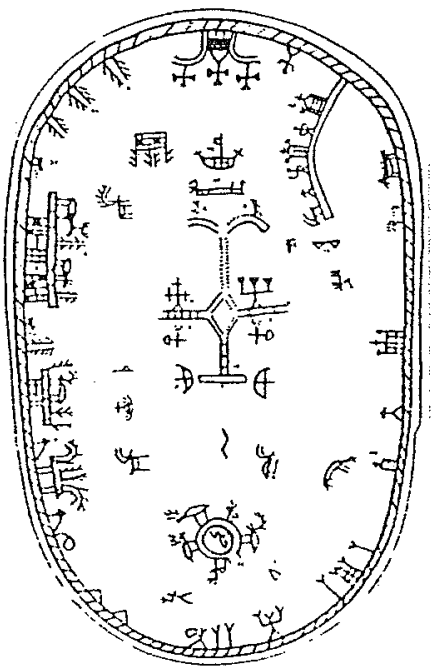

Fig 8d D rum number 32 (Manker 1950) 


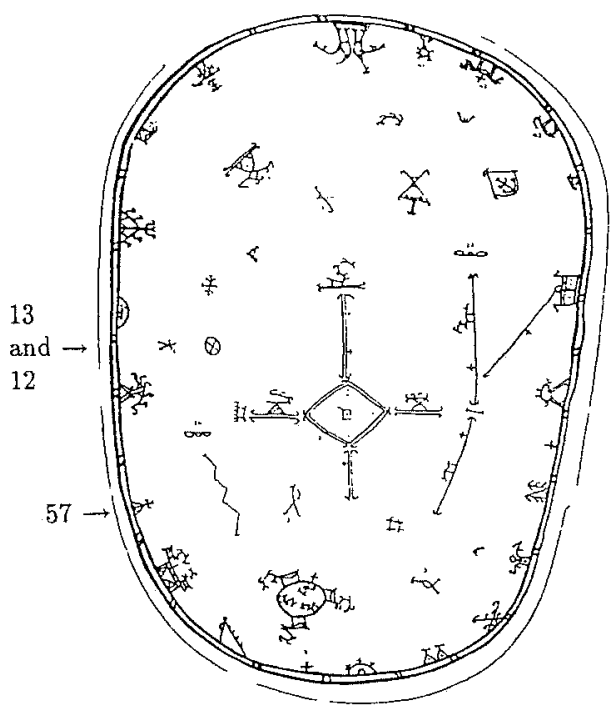

Fig 8 De Drum number 19 (Manker 1950)

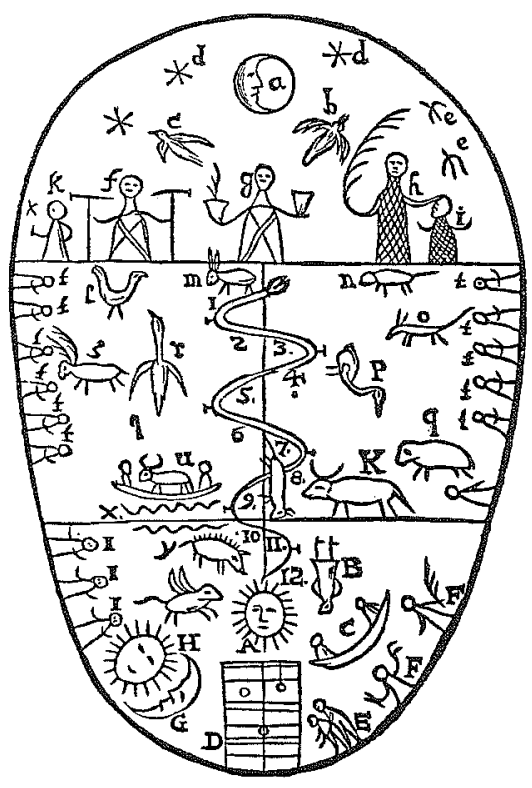

Fig 9 Drum L (Manker 1950, fig 16)

motif is situated below the symbol of the sun but quite close to its "rays" (Fig 8d)

I have counted the motifs surrounding the figures of the snake or zig zag and the numbers are recorded in tab $1 B$ As may be seen, the most numerous is the Saami village or Saami hut (kota), on 17 drums, but two of the interpretations of the figures are not clear The following items in the list are the offering place (16), the sacrificial animal (13-1), the reindeer/reindeer herd/reindeer-fencing (10), the man/skier/fisher (8-1), the storehouse (6), fishing net/fishing boat or lake (9-4) The category "some divinity" includes various deities: four of these are Ailekesolmaks (the men of the festival) and one is supposed to be some god or shaman

The last mentioned is figure 57 in drum 19 (Fig 8e) As figures 13 and 12 on the same drum are explained as "a shaman and a drum" figure 57 is therefore "a god" rather than "a shaman" The identifica tion "a shaman and/or his drum" has been mentioned in 6 cases but three of these are uncertain The shaman's reindeer (nolade sarva) or some other animal of a shaman can be found in 8-1 cases (Tab 1B)

"The underworld/otherworld" occurs in comments on three drums 
and in all of them with question marks, meaning that the statements provided are not certain On drum 11, according to Manker, it is the four cornered figure at the end of the sun's rein (labikie) that points downwards In the other one, drum 12, the figure formed by curves and lines is so unique that no help may be derived from the signs on the other drums Nor does the location of the figure help, because it is too unusual to be a place in the underworld

The motifs of the bear and beaver are puzzling, since, in addition to being hunting objects, they also had mythical meanings $\mathrm{A}$ common feature in most motifs near the snake or zig zag is that they are connected with the everyday life and material existence of the Saamı people The same is also true of the sign of the sacrificial animal for Horagalles (Tiermes), because this god was the oldest, very highly honoured and believed to be the protector of reindeer (Andelin 1858, $242 \mathrm{f}$ )

Some interpreters have referred to the snake by the words "nolade kärmai", shaman's snake or "guolle", the fish, but they have mostly used only the word "snake" According to some informants, the snake was a disgusting creature (ein verabscheutes Lebewesen), and there is no reason to doubt the statement The people's attitude towards the snake was so hostile in Lapland that they would kill even an innocent lizard as well as a snake, says T I Itkonen (Itkonen 1948, 373) But we must bear in mund that all the comments about the snake are from the last two centuries and therefore relatively late

In the Asele drums the figures of the snake do not at all correspond to the attribute 'disgustıng', as may be seen in tabs $1 \mathrm{~A}$ and $1 \mathrm{~B}$ And besides this, there is another notable feature: on the Asele drums the snake is on the opposite side to the other-or underworld, Salvo-, Jabme- or Rota-aimo, whose figures are to the right of the sun symbol The only exception, drum 36, even seems to confirm the rule, if the sign of a tree is really the symbol of growth (Wachstumsymbolen) and the zig-zag means a snake

Anders Andelin, in hıs article "Kertomus Utsjoen pitäjästä", offers a piece of information which may help us to understand the location of the snake-motif on the drum heads According to Andelin, the Saamis believed that the dawn was made by Radien and evening twilight by Rota, and also that the sign of twilight was painted near the figure of Rota aimo (Andelin 1858, 264) This information corresponds well with Frees' drum II (Fig 8c) Here, the sign of morning glow (fig. 3) is in the Radien group and the sign of sunset glow (47) on the right quite close to Rota aimo In another drum, Rudbeck's L (Fig 9), the 
figure marked by the letter $\mathrm{k}$ standing in the upper section on the left has been identified as "the servant" (Diener), whose job was to hang up the morning star In the other drums, such as numbers $43: 17$ and 64: 5 , these interpretations are not so reliable

The information provided by Andelin, Frees and Rudbeck prompted me to examine the drum from such a position that the upper part of the drum head faces towards the south The right side of the drum then points towards the setting sun, and the signs of the other world and underworld are then also in the west

The scheme suggested would not be in conflict with the beliefs according to which the underworld is literally a subterranean place In petroglyphs, the boats with an elk head or some other symbol of the sun in the prow may be understood only with the help of Osiris's sun boat and the beliefs accociated with it The sun-boats in the rock pictures in the Caucasus, Scandinavia, Finland and Siberia (e g Formozov 1966, 45) show that ancient man needed an explanation for the daily route of the sun If the sun set in the west and rose in the east, it had to get from the west to the east through the subterranean space which was imagined to be like a sea This is why the other world could be in the west and under this world

The figures of some boats on the Saamı drums may be relics of this belief The Scandinavian word "Rınghorna", used by Rudbeck, refers to this The figure of a reindeer or its antlers inside the sun-symbol may be another relic from the past If the figure inside means the anımal which had to be sacrificed to the sun, then how is it possible that in drums $17^{2}$ and $63^{3}$ there is a picture of a human being in the same place? It is more consistent to see the figures of both reindeer and human being as images of the sun personfied Then the figure may also depıct the Kolta-Saami's Mandash-pyrre, the mythıcal reindeer, whose golden antlers shone like the sun (Charnoluskij 1965, 74, 80; Okladnikov-Martynov 1972, 227)

These are not the only ancient features in the pictures on the drum head Perhaps the most significant likeness can be found in the figure combination where a god holds similar spade-like objects, placed on elther side of him (Fig 10a) There is an analogous scheme, xAx, in the composition of the so called "pole carrier" in the petroglyphs of

2 Because the figure is like other signs of gods, it does not depict the owner of the drum, cf fig. 45

${ }^{3}$ The figure hardly depicts a bird of fig. 20 See also the signs in drums 5:11, 42:1 and 69:2 


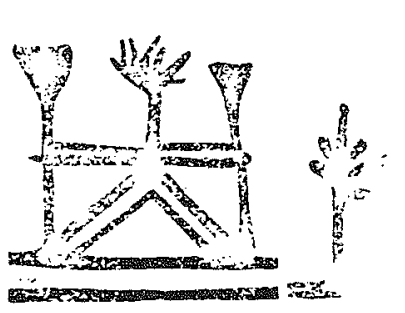

Fig 10a Figures of gods (Manker 1950, 5:b, 64:2)

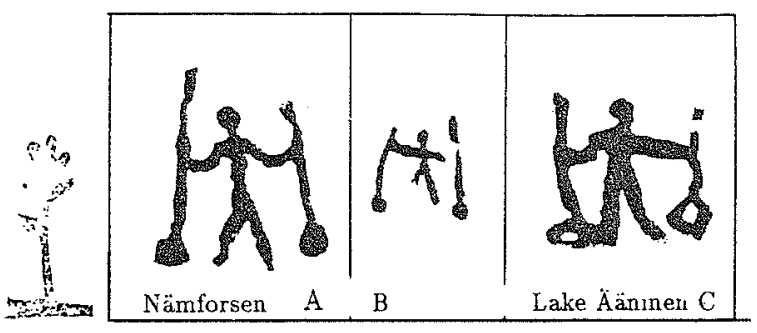

Fig $10 b$ "The pole carrier man" in the petroglyphs of Nämforsen $A-B$ and Ääninen C (Hallström 1960 319)

Äänınen and Nämforsen (Fig 10b) A sımilar ıconographıc scheme is found in some Ob-Ugrian silver plates, although the things in the hands of the man are swords (Spitsyn 1906, figs 5 and 7) The scheme can also be recognized in the iconography of the famous Cretan SnakeGoddess

The fourth archaic feature seems to be in the figures of gods with three horns or vertical lines in place of the head (Figs $11 \mathrm{a}-\mathrm{f}$ ) Almost identical figures can be seen in the rock pictures of Alta, in the Kolapeninsula, at Hossa in Finland, in the Urals and in Siberı, but not in Southern Scandinavia (Figs $11 \mathrm{~g}-\mathrm{k}$ ) The motif also occurs in the Permian bronze works, Ob Ugrian plates, in the Western Siberian bronze age cultures, and in Buryatian ongons (Figs $11 \mathrm{l}-\mathrm{p}$ )

The analogies in the pictures on drum heads and in petroglyphs lend additional support to the conclusion that the other world of the Saami people was previously situated in the west From this, it follows that the east was not an evil or unfortunate direction as it seems to be in the world of the Edda (Tynn 1980, 12) The location of the snake in the direction of the rising sun therefore meant something good.

Two sculptures of a snake fig 12, found in graves in the region of Ä̈nınen and dated to the end of the mesolithıc era show that beliefs: associated with them had a positive meaning No mourning relative puts anything unpleasant into a grave For this reason, and for the meaning attached to the snake in the Scandinavian petroglyphs and in the Danish votive offering, I shall pass over the beliefs coloured by Christian farth as well as the Scandinavian serpent, Nidhoggr

In ancient Egypt, "the primeval Serpent, the most Ancient One" was the symbol of creation and held all subsequent creation within its folds at the beginning of the world In coffin texts the words of the Gods were announced from the mouth of the Serpent (Clark 1960, 

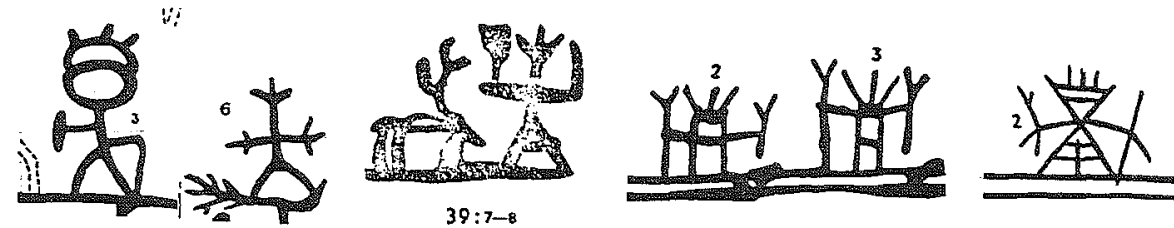

Fig 11 a-f Three horned gods in Saaml drums (from the left: 69:3, 31:6, 39:8, 50:2-3, 47:2) Also in drums 5, 30, 51, 54, 55, 59, 60, 61, 69, 68 (Manker 1950)

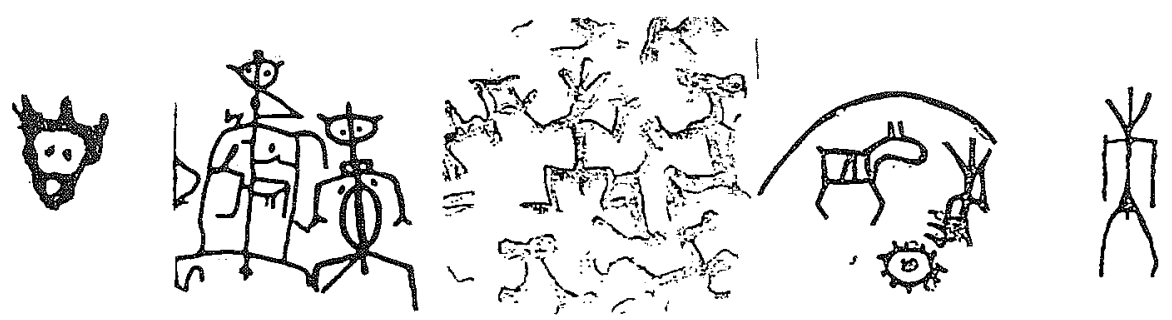

Fig $11 g-k$ Three horned human like figures in rock pictures, from the left: Hossa in Finland (Taavitsainen 1979, 110); Alta (Helskog 1988, 66); Kola penınsula (Gurna 1980, 126); the Urals (Gjessing 1978, 24 f); Siberı (Ivanov 1954, 97)
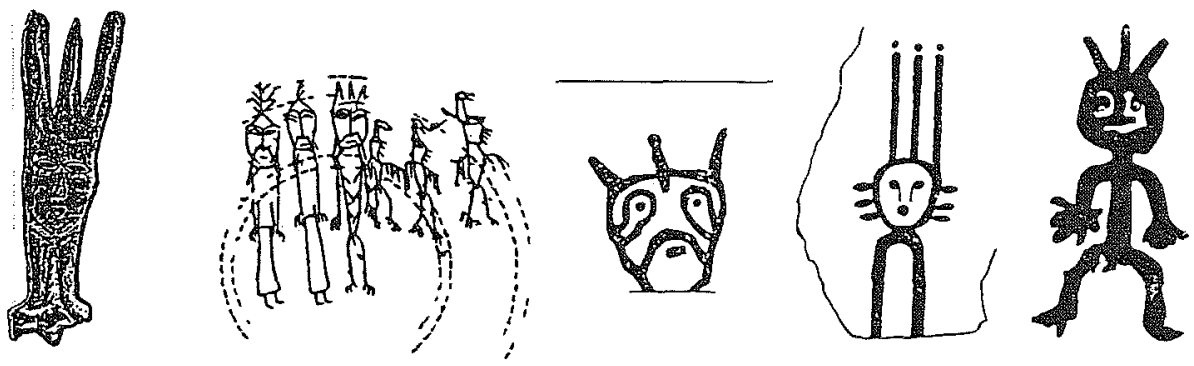

Fig 11 l-p Three horned human-like figures, from the left: a Permuan bronze work (Aspelin 1877, 129) an Ob-Ugran plate (Chernetsov 1953, 157); a Minusinskian carving (Studzıtskaja 1987, 81); in the pottery of Samus IV culture (Studzitskaja 1987 79); in a Buryatian ongon (Ivanov 1954, 708)

\section{$51 \mathrm{ff}, 75,95,106 \mathrm{f}$ )}

One of the best known deities of ancient Crete is the Snake Goddess At Knossos, in a private house, there seem to have been small cups for feeding the snake, which was honoured as the spirit of the house personified The snake was also the symbol of the underworld and of fertility, and it had the same function in Mycenean Greece (James $1959,129 \mathrm{f}$ ) The snake emblem of Pallas Athene symbolized the vege tative powers and also the duty of guardian mantained by the goddess (Levy 1946, 221) The ancient Celts had almost sımilar beliefs: in 
Fig 12 Snake sculptures from the ancient semetary of Peurasaarı on Lake Äänınen (Gurma 1956, fig 133)

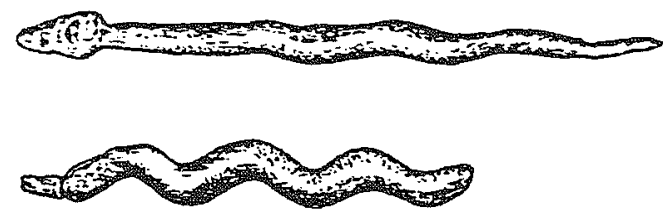

their iconography, the snake depicted fertility and, as the emblem of Bridged, its function was to ward off evil powers (e $\mathrm{g}$ Cooper 1983)

According to Finnssh folk poetry, the snake seems to appear in the role of guardian of the underworld, and even as messenger, in the rune "Sun and Moon" (Finnısh 1977, poem 31) The snake was kept in the cow sheds, and particularly in folk beliefs a horn or crown headed snake was the omen of fortune and wealth (Ruuttu 1929; Haavio 1939, $46 \mathrm{ff}$ ) The same kind of beliefs existed in Estonia According to information recorded in Viljandi, the snake brought wealth and fertility, and helped to maintain links with ancestors (Merı 1983, 125)

\%

In the drum heads divided into two or more sections the figure of a snake or zig zag is marked in 13 of them, table 2 Most usually it is situated in the lower or lowest sections and has a clear connection with the underworld or other world (Jabme or Rota almo) or the Orre Sea, the place where the sun and moon were believed to be during winter

In drums 61 and 70 the snake is near the figures of the moon According to Frolov, the combination can be seen in the pre historic matenal up to the bronze age (Frolov 1974, 125) The ability of the snake to slough its skin has been associated with the phases of the moon, its death and rebirth and also with the idea of renewal

A fairly interesting snake figure for its location is to be found on drum 69 , and especially on the drums, Rudbeck $\mathrm{K}$ and L On these, the snake is situated on the central line of the drum head, as in drum L, fig 9 According to Rudbeck, the three lowest bends (12-10) of the snake symbolize the darkest time of the year and the upper ones (91) the other months The idea that the snake was connected with the passing of time is not entirely impossible, as suggested above At 


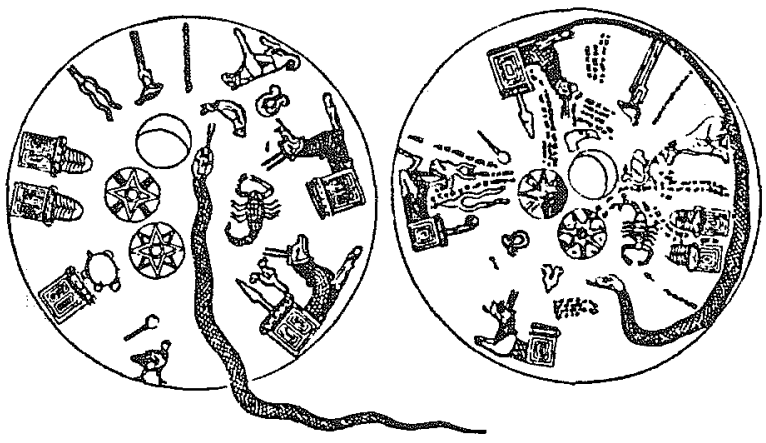

Fig 13 Babylonian drawlngs supposed to be old signs of the zodiac (Tallquist 1943, 10)

least, it had a quite outstanding place in the oldest signs of the zodiac, fig 13 .

There is another feature in the snake on drum $L$ and also on Rudbeck's $K$ which may have some significance These are the small appendages at the bends of the snake and zig-zag Although they are not quite identical to the figures in the petroglyphs, figs 2, 6c and $7 \mathrm{a}$, they may help us to understand one more function of the figures under discussion during the time of the petroglyphs

The snake and zig-zag motifs are used in the decorations of the wooden bowl like trunks of some drums $(17,51,55,59-63,67$ and 71) In one of them, fig 14, the zig-zag carving seems to go round the middle part of the bowl It is worth mentionung, however, that these kinds of decoration do not occur in the pure Asele-type The motif was also used in the decorations of some hammers

Some informants have called the ring or cluster of rings (vuorra, arpa $=\mathrm{a}$ lot) by the words "snake" or "frog" The words may be relics, however, since there is nothing in the shape of these objects which could resemble a snake or a frog

The main problem with the interpretation of Finnısh rock paintıngs is the significance of shamanısm, as I stated in the introduction After surveying the "most shamanistic" motif in the rock art and Saamı drums I am ready at least for the following conclusions:

1) There are other possibilities besıdes shamanım for constructıng an interpretation of the rock paintings. The votive offer in the composition at Sarakallio shows clearly enough that the ancient hunters also absorbed influences from the south In this, I agree with Okladnikov and Formozov, who have pointed out that 1deas could travel from 
Fig 14 Drum number 71. (Manker 1938)

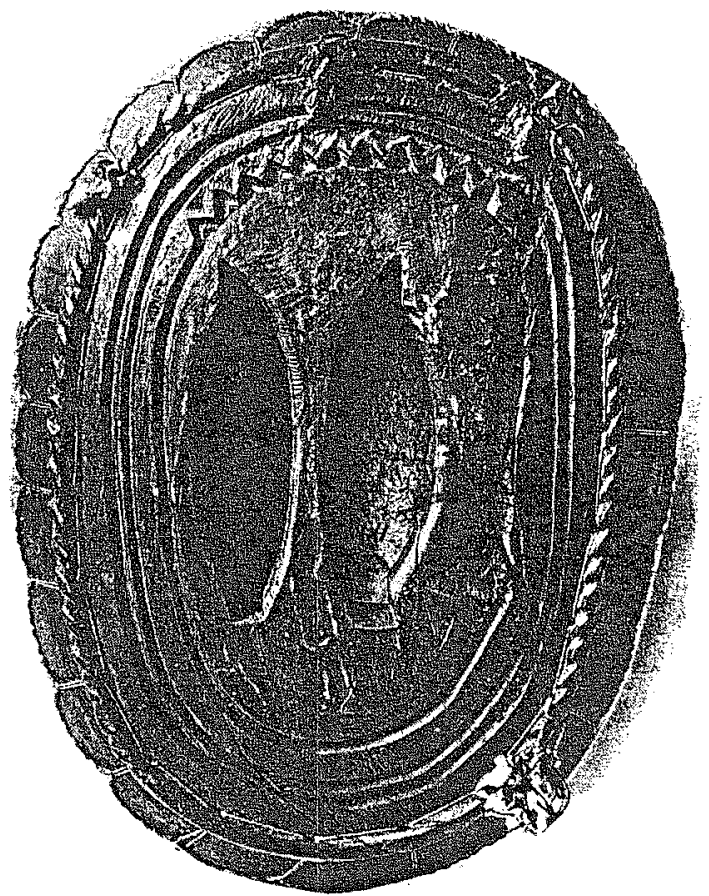

south to north as easily as "the Siberian pine to Finland" (Okladnikov \& Martynov 1972, 237-42; Formozov 1966, 124 f; Formozov 1987, $40 \mathrm{f}$ ) Furthermore, the composition in which the human beings are copulating like anımals has a counterpart in the south but not in the Urals or in Siberia

2) The copulation scene and votive offering at Sarakallio show clearly that ancient man did not resort to the shaman but to magic and to the cults of fertility and ancestors The number of elk bones in the comb-ceramic culture indicates that the hunters were very skilled in catching their prey Their greatest problem seems to have been the numbers of anımals and this explasns the need of the fertility magic

3) These observations and conclusions lead me to doubt whether the compositions in which there is a human being and a snake are to be explained only on the basis of shamanism If the ancient hunter had different human like gods or mythical beings, he had to show them by emblems like the snake, horns etc (also Formozov 1987, 92-6) Only the hybrids of a human being and a snake in Juusjärvi: and Kolmiköytınen seem to indicate shamanısm, but there is also: a possibility that they may depict some imaginary spiritual being: unknown to us In those compositions in which the other figures 
near the snake or zig zag indicate fertility or ancestor cults, the snake belongs to the same complex of beliefs The figures of snake and elk together probably refer to magic or to the cult of fertility

4) The statements concerning the snake motif on Saami drums are not directly applicable to the rock pantings On the Asele type drums the location of the snake and zig-zag motifs and other figures near them seems to follow some older tradition This is indicated by the position of the snake on the left side of the drum heads, because it can be seen as the direction of the rising sun The figures of Lapp village, sacrificial site etc near the snake give support to the idea that the older meaning of the snake was in some way positive, and that it had a connection with prosperity There are also other figures on drum/heads which seem to be relics from the past The most indisputable of these are the figure of a god with spade like emblems on both sides and the gods with "three horns"

5) On the drum/heads divided into two or more sections, the snake, its connection to the other motifs, and snake like zig-zag decorations on the trunks of some drums seem to support the hypothesis of Skanke Jessen It is nonetheless likely that, for the ordinary user of the drum, when the purpose was to inquire into future invents, the snake had a role in showing the will of the gods In particular, the names of the ring (snake, frog) refer to that possibility The snake's connection with time, as in drums Rudbeck $\mathrm{K}$ and $\mathrm{L}$, may have some significance in the context of rock pictures 
Table 1 The snake and zig-zag motifs on the Asele-type drums

Asele-type drums, totalling 47 drums (44 available +3 not available) with the snake or zig-zag on 30 drums ( 28 available +2 not available)

A

The location of the motif:

on the left of the sun-symbol

below the sun-symbol

on the right of the sun-symbol

near the sun-symbol

farther from the sun-symbol

$\begin{array}{cc}\text { total } & \text {-unsure } \\ 28 & 1^{1} \\ 1 & \\ 1^{2} & 1 \\ 12 & \\ 18 & \end{array}$

B

The motifs near the snake or zag-zag

Saamu village/hut (kota/lager)

total -unsure

offering place/holy-mountain (passe/passevarre)

$17 \quad 2$

sacrificial anımal (to Horagalles)

16

reindeer/reindeer-herd/reindeer-fencing

131

$\mathrm{man} / \mathrm{skler} /$ fisher

storehouse (njalla)

10

fishing net/fishing boat/lake

some divinity

shaman/drum

shaman's reindeer (nolade sarva)/other shaman

$8 \quad 1$

6

94

$9 \quad 1$

63

animal

bear

$8 \quad 1$

beaver

52

fur-bearing animal

$5 \quad 2$

underworld/other world (Sarvo-/Jabme-/Rota-aimo)

41

tree

$3 \quad 3$

$1^{3}$

1 Drum 14 figure 18; the interpretations: "Wasserlauf Fischgewässer (? ev: Schlange)"

2 Drum 36, figure 8, The undefined zig zag

3 Drum 36, figure 24, the interpretation: "Wachstumsymbole, Baumgeister (?)" 
Table 2 The drum heads divided into two or more sections

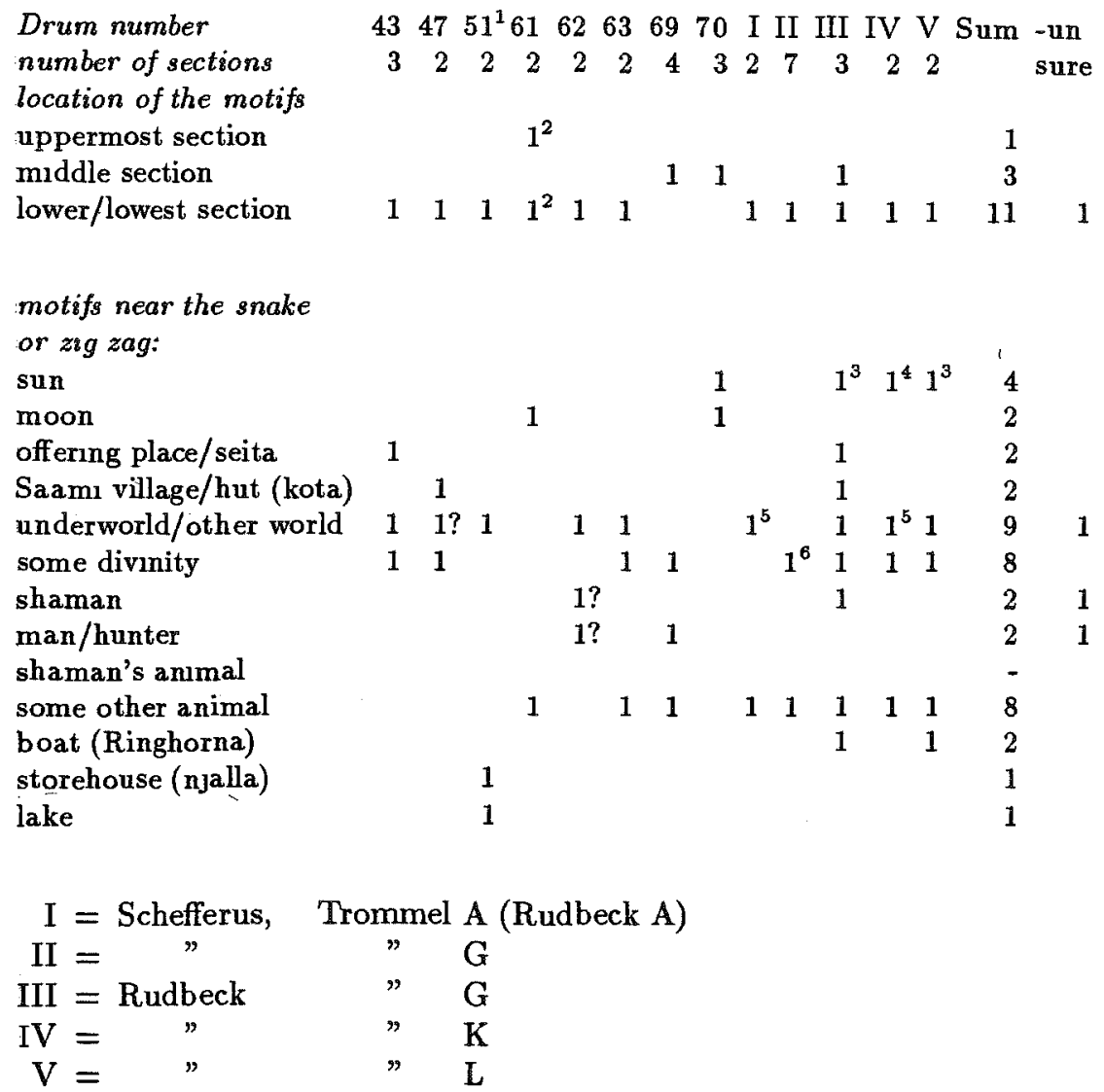

\footnotetext{
1 Figure 22 with the zig-zag line; interpretation: "Fischgewässer", "Bach"

2 There are many zig zag motifs, the snake fig 13

3 The sun in winter

4 Two suns: one in winter and the other as usual

5 The Ondan Sea

6 Tod (döden)
} 


\section{Bibliography}

\section{UNPUBLISHED SOURCES AND LITERATURE}

Helstnk

MV Museovirasto

Luho, V 1964, Kirkkonummı, Österby, Juusjärvı Kertomus kalliomaalausten tutkimisesta

Miettınen, M \& Miettınen T 1978 Copies of the rock paintıngs of Sarakallio Tarto

EAGA Esthonian Astronomia and Geodesia Association

Estonian exploring group Copıes made on the eastern shore of Lake Aänınen in 1986-1988

\section{Turku}

TY Turun Yliopssto Esihıstorıan laitos

Miettınen, T [1987] Kalliotaiteemme tulkintaongelmista A paper read at the Symposium on Rock-Art held at Turku, Finland, on the 28th-29th of September 1987

\section{PUBLISHED SOURCES AND LITERATURE}

Andelin, A 1858 Kertomus Utsjoen pitäjästä Suomı 1858 Helsingfors Aspelin, J R 1877 Muınaısjäännöksıä Suomen suvun asumus-aloilta Helsınkı Autio, E 1981 Karjalan kalliopiirrokset Keuruu

- 1984 Hirvı ja käärme Uikujoen kalliossa Kotiseutu Helsınkı.

Burenhult, G 1979 Hällbilder från sten- och bronsålder \& Norden Malmö Museum Malmö

Charnoluskij, V V 1965 Легенда об олене-человеке Москва

Chernetsov V N 1953 Бронза Усть-полуиского времени Древняя история Нижнего Приобья Москва

- 1964 Наскальные изображения Урала I Москва

- 1971 Наскальные изображения Урала II Москва

Clark R T Rundle 1960 Myth and symbol in Ancuent Egypt London

Cooper, J C 1983 Symboler Helsingborg

Finnish folk poetry Epıc 1977 Ed and transl by M Kuusı Helsinkı

Formozov, A A 1966 Памятники первобытного искусства на территории СССР Москва

- 1987 Наскальные изображения и их изучение Москва

Frolov, В А 1974 Числа в графике палеолита Новосибирск

Gjessing, G 1978 Rock-pictures in Northern Fenno-Scandia and their eastern affinities Acts of the international symposium on rock art $\mathrm{Ed}$ by S Marstrander (Instituttet for sammenlignende kulturforskning A, 29) Oslo

Gurına, N N 1956 Ојенеостровскии Могилвник Материалы и исследования поархеологии СССР Москва 
Gurina, N N 1980 Наскальные рисунки Кольского полуострова ип сопредельных областе Звери в камне Новосибирск

Haavıo, M 1939 Huomıita suomalaısen kansanperunteen kartoittamısesta Virittäjä 43 Helsinkı

Hallström, G 1960 Monumental art of Northern Sweden from the Stone Age Stockholm

Helskog, K 1985 Selective depictions A study of 3,500 years of rock carvings from Arctic Norway and their relationship to the Sami drums Archaelogy as a long term history Cambridge

- 1988 Helleristningene i Alta Aba Museum Alta

Holmberg, U 1914 Permalasten uskonto Porvoo

Itkonen, T I 1948 Suomen lappalaıset vuoteen 19452 Porvoo

Ivanov, S V 1954 Материалы по изобразительному искусству народов Сибири XIX-начала XX в Москва

James, E O 1959 The cult of the Mother-Goddess An archaeological and documentary study London

Levy, G R 1946 The Gate Horn A study of the religious conceptions of the Stone Age, and their influence upon European thought New York

Linevski, A M 1939 Петроглифы Карелии Ч I Петрозаводск

Luho, V 1962 Klippmålningen vid Juusjärvi Finskt Museum 69 Helsingfors

MacCana, P 1983 Celtic mythology London

Manker, E 1938 Die lappısche Zaubertrommel 1 (Acta Lapponica 1 ) Stockholm

- 1950 Die lappische Zaubertrommel 2 (Acta Lapponica 6) Stockholm

Merı, L 1983 Hopeanvalkea [Transl by] E Lille Jyväskylä

Miettınen, T 1982 Kuvat kalliossamme / Pictures on the Finnzsh rocks Helsinkı

Ojonen, S 1973 Hällmålnıngarna vıd sjöarna Kotojärvı och Märkjärvı ı Iittı Finskt Museum 80 Helsingfors

Okladnikov, A P 1966 Петроглифы Ангары Москва-Ленинград

Okladnikov, A P \& Martynov, A I 1972 Сокровища томских писаниц Mocква

Okladnikov, A P \& Petrin, V T 1983 Палеолитические рисунки Игнатиевскоћ пещеры на Южном Урале Пластика и рисунки древних культур Новосибирск

Raudonikas, V I 1936-38 Наскальные изображения Онежского озера и Белого моря I-II Москва-Ленинград

Ruuttu, M 1929 Eläinmaailmaa kannakselassten uskomuksıssa Virittäjä 33 Helsinkı

Ränk, G 1949 Kysymys Lapın Madderakasta ja hänen tyttärıensä alkuperästä Kalevalaseuran vuosikirja 29 Porvoo

Salo, U 1984 Pyyntikulttuurista maanviljelyyn Sukupolvıen perıntö 1 [Ed by] E Kirkınen \& T Hakamäkı \& M Lınkola Helsinkı 
Sarvas, P \& Taavitsaınen, J -P 1975 Käköveden kalliomaalaukset Kotiseutu Helsinkı

Savvatejev, J A 1983 Наскальные рисунки Карелии Петрозаводск

Schlette, F 1976 Kelten zwischen Alesıa und Pergamon Leibzig

Siikala, A-L 1980 Mitä kalliomaalauksemme kertovat Suomen kampakeraamisen väestön uskomusmaailmasta Suomen Antropologı 1980, 4 Helsink

Sommarström, B 1987 Ethnoastronomical perspectives on Saami religion Saamı religion Ed by $\mathrm{T}$ Ahlbäck (Scripta Instıtutı Donnerıanı Aboensis $12) \AA ̊ ̊ b o$

Spitsyn, A A 1906 Шамвнские изображения, 30РCA, т VIII, вып 1 MockB8

Studzitskaja, S V 1987 Изображенпе человека в искусстве древнего населения Урало-Западносибирского региона Антропоморфные изображения Первобытное искусство Новосибирск

Taavitsamen, J -P 1979 Suomussalmen Värikallio Kotiseutu Helsınkı

Tallqvist, K 1943 Eläinrata (Suomen itämaısen seuran kansantajuısıa julkaisuja 10 Suomen tredettä 2 ) Helsınkı

Tynnı, A 1980 Johdanto Eddan sankarırunot [Transl and ed by] A Tynnı Porvoo

Waronen, M 1895 Varnajainpalvelus muınazsilla suomalarsilla Helsinkı 